\title{
THYRONECTRIA DENIGRATA (WINTER) SEAVER, THE CAUSE OF DISEASE IN GLEDITSIA
}

\author{
Edgar V. Seeler, Jr.
}

Two Heretofore UNDESCRIBED DISEASES of Gleditsia have been studied by the writer during the past three years. One is a wilt of $G$. japonica Miq. and the other a canker of $G$. triacanthos L. The former is certainly caused by Thyronectria denigrata (Winter) Seaver (Pleonectria denigrata Winter), a fungus so far recognized as a saprophyte only, and the latter seems to be caused by the same fungus. The wilt disease was observed in the Arnold Arboretum, and the canker on Nantucket Island, Massachusetts.

Gleditsia japonica is represented in the Arnold Arboretum by a few trees raised from seed of Korean origin, received in 1904. These trees grew well. But in May 1933 one of them suddenly wilted and died. A second one died similarly in October 1937 and a third in August 1938. The symptoms throughout resemble those of the Dutch Elm Disease both as to wilting of the foliage and discoloration of the wood. The discoloration is of a red-orange color (Bittersweet Orange darkening on air exposure to Grenadine Red, Ridgway).

Cultures from the stained areas in all cases developed the same fungus. On potato-dextrose agar this appears first as a low mat of fine white mycelium which later produces from simple conidiophores many small, single-celled, oval, hyaline spores. Soon parts of the agar surface become covered with a wettish orange-colored mass of spores and these bud much in the manner of yeasts. This phase might be classified as a Sporotrichum. As the cultures dry out, provided they are exposed to light, the mycelium balls up to form white, felted, botryoidal pycnidia with black top-surfaces which crack and exude orange-colored cirri of spores of the same size and shape as spores newly borne on the earlier hyaline conidiophores. Cultures kept in the dark do not show pycnidia and the color of the mycelium appears yellower.

Logs cut from the diseased trees showed after a few weeks pycnidia with cirri of orange spores but produced on stromata which protruded through the lenticels. Spores from these grew in culture exactly as did the isolations from discolored wood. The stromata and pycnidia and 
cultural characteristics are identical in every way with those of stages of $T$. denigrata from $G$. triacanthos.

Numerous attempts to produce ascospores in culture have not been successful. Single ascospore cultures of $T$. denigrata have been made, however, and all details of growth of the fungus up to the production of pycnidia on large stromata have been found exactly similar in fungi from both sources. Moreover, immature perithecia like those of Thyronectria have been found on overwintered branches of the diseased G. japonica. Experimental proof was obtained by inoculating 30 seedlings of $G$. japonica. Forty per cent of the seedlings became infected and soon died. Thyronectria denigrata was readily isolated from the discolored wood and no other fungus was present. From the facts that the trees in question died suddenly, that discoloration and hyphal threads were found throughout the same annual ring of the trunk and branches, and that they were limited to the vessels, it is deduced that once infection starts the fungus is a very active parasite in $G$. japonica. Small conidia seen in the vessels no doubt hasten the spread of mycelium in the tree.

In the literature $T$. denigrata, though often collected on American gleditsias, has not been suspected of being a parasite. However, the author has observed many trees of $G$. triacanthos on Nantucket Island where some signs of parasitism following severe winters were apparent. In some instances fatalities resulted. Cankers were the conspicuous symptoms and no wilting was observed. In these trees at the border of infected wood was a red-orange line of demarcation localized to the canker, and not widespread as in G. japonica. Cultures indicated that $T$. denigrata was the causal organism.

Laboratory of Plant Pathology, Arnold Arboretum, Harvard University. 


\section{$2 \mathrm{BHL}$ Biodiversity Heritage Library}

Seeler, Edgar Viguers. 1939. "Thyronectria denigrata (Winter) Seaver, the Cause of Disease in Gleditsia." Journal of the Arnold Arboretum 20(1), 114-115. https://doi.org/10.5962/p.185401.

View This Item Online: $\underline{\text { https://www.biodiversitylibrary.org/item/33596 }}$

DOI: https://doi.org/10.5962/p.185401

Permalink: https://www.biodiversitylibrary.org/partpdf/185401

\section{Holding Institution}

Missouri Botanical Garden, Peter H. Raven Library

\section{Sponsored by}

Missouri Botanical Garden

\section{Copyright \& Reuse}

Copyright Status: In copyright. Digitized with the permission of the rights holder.

Rights Holder: Arnold Arboretum of Harvard University

License: http://creativecommons.org/licenses/by-nc-sa/3.0/

Rights: https://biodiversitylibrary.org/permissions

This document was created from content at the Biodiversity Heritage Library, the world's largest open access digital library for biodiversity literature and archives. Visit BHL at https://www.biodiversitylibrary.org. 